\title{
Cadherin Expression in the Nigerian and United Kingdom Breast Cancer Cases: A Comparison of Clinicopathological and Prognostic Characteristics
}

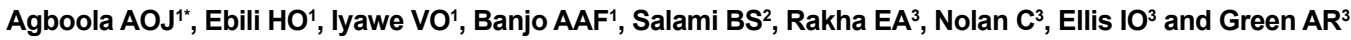

${ }^{1}$ Department of Morbid Anatomy and Histopathology, Olabisi Onabanjo University, Sagamu, Nigeria

${ }^{2}$ Department of Surgery, Olabisi Onabanjo University, Sagamu, Nigeria

${ }^{3}$ Division of Cancer and Stem Cells, Nottingham University Hospitals Nottingham, United Kingdom

\begin{abstract}
Background: The expression of the cadherins have been shown to have both clinicopathological and prognostic significance in breast cancer from different ethnic populations. However, the clinicopathological and prognostic significance of the cadherins expression in Nigerian breast cancer (BC) have hitherto not been determined. The aim of this study was therefore to describe the expression patterns of E- and P-cadherin in Nigerian and United Kingdom (UK) BC cases and to compare the clinicopathological and prognostic significance of the cadherins between the two cohorts.
\end{abstract}

Methods: Tissue microarray of about 266 formalin-fixed paraffin-embedded Nigerian and 301 UK BC samples with well-characterized clinicopathological indices were subjected to immunohistochemical staining for $\mathrm{E}$ - and $\mathrm{P}$-cadherins and other biomarkers. These biomarkers were correlated with the patients' clinicopathological and prognostic data using the appropriate statistical tests on SPSS. A p value of $<0.05$ was taken as statistically significant.

Results: A lower rate of E-cadherin expression was found in the Nigerian cohort (29.2\%) compared to their UK counterparts $(54.8 \%)$. However, the rate of P-cadherin expression was similar in both Nigerian $(53.4 \%)$ and UK $(52.9 \%)$ series. While E-cadherin expression showed no pathobiological significance in the Nigerian cases, it was associated with favourable clinicopathological features in the UK cohort. P-cadherin on the other hand was associated with adverse clinicopathological features, including the triple-negative and basal-like BC subtype in both $\mathrm{BC}$ populations. However, we found no prognostic significance for either $\mathrm{E}$-cadherin or $\mathrm{P}$-cadherin in both $\mathrm{BC}$ cohorts.

Conclusion: While P-cadherin expression is high in both the Nigerian and UK BC cohorts and might therefore function as a biomarker for the basal-like BC, E-cadherin expression was associated with favourable clinicopathological indices in UK, but not in the Nigerian, cohorts.

Keywords: Nigerian and United Kingdom breast cancer; E-cadherin; P-cadherin; Clinicopathological

Abbreviations: BC: Breast Cancer; EMT: Epithelial Mesenchymal Transition; NOS: Not Otherwise Specified; BCSS: Breast CancerSpecific Survival; DFI: Disease-Free Interval; CK: Cytokeratin; EGFR: Epidermal Growth Factor Receptor; ER: Oestrogen Receptor; PR: Progesterone Receptor; BRCA1: Breast Cancer Antigen 1; HER2: Human Epidermal Growth Receptor 2

\section{Introduction}

Tumour cell invasion and metastases are facilitated by the epithelial mesenchymal transition (EMT) which is in turn associated with changes in expression of the different isoforms of cadherin cell adhesion molecules [1-3]. These isoforms which include E-cadherin, $\mathrm{N}$-cadherin, $\mathrm{P}$-cadherin, amongst others, have specific normal tissue expressions [1-3]. For example, E-cadherin is expressed is normally expressed in epithelial tissues where it mediates cell-cell adhesions, limits cell motility and establishes apicobasal polarity [1]. N-cadherin is expressed in mesenchymal tissues where it mediates focal adhesion of mesenchymal cells with the extracellular matrix components and cell motility [1,2]. P-cadherin is expressed by myoepithelial cells in which it maintains the myoepithelial cell undifferentiated state which is necessary for orderly differentiation of glandular structures $[1,3]$.

In malignant epithelial tumours such as breast cancer, the EMT is characterized by down-regulation of E-cadherin expression and upregulation of $\mathrm{N}$-cadherin, or aberrant co-expression of $\mathrm{P}$ - and E-cadherins [1-3]. The expression patterns of the cadherins have been shown to have both clinicopathological and prognostic significance in breast cancer from different ethnic populations [1-9]. Specifically, E-cadherin loss in primary breast cancer is associated with high grade tumour and positive lymph node status and confers shorter survival characteristics on patients [4-8]. Such poor prognostic indices have also been observed in breast cancers with high expression of $\mathrm{N}$ - and P-cadherins [1-3,9]. However, the implications of the aberrant expression of the cadherins in the Nigerian breast cancer population have yet to be investigated.

The aim of this study is to determine the clinicopathological and prognosticsignificance of the cadherin switch in Nigerian women with breast cancer compared to their United Kingdom counterparts. We investigated the expression of E-cadherin and P-cadherin using Tissue Microarray and Immunohistochemistry and compared the clinicopathological features and survival characteristics of $\mathrm{E}$ - and P-cadherin expression between the Nigerian and the United Kingdom cases.

\section{Materials and Methods}

The Reporting Recommendations for Tumour Markers Prognostic Studies criteria were followed in this study [10]. Ethical approval was obtained both from the Medical Advisory Committee of the Olabisi Onabanjo University Teaching Hospital and by the Nottingham Research Ethics Committee 2.

*Corresponding author: Dr. Ayodeji O.J. Agboola, Department of Morbid Anatomy \& Histopathology, Olabisi Onabanjo University, P.M.B 2001, Sagamu, Ogun State, Nigeria, E-mail: Johndeji2001@yahoo.co.uk

Received June 09, 2016; Accepted June 19, 2016; Published June 25, 2016

Citation: Agboola AO, Ebili HO, lyawe VO, Banjo AAF, Salami BS, et al., (2016) Cadherin Expression in the Nigerian and United Kingdom Breast Cancer Cases: A Comparison of Clinicopathological and Prognostic Characteristics. Surgery Curr Res 6: 271. doi:10.4172/2161-1076.1000271

Copyright: (c) 2016 Agboola AO, et al. This is an open-access article distributed under the terms of the Creative Commons Attribution License, which permits unrestricted use, distribution, and reproduction in any medium, provided the original author and source are credited. 


\section{Patients}

The Nigerian and United Kingdom cohorts used in this study comprised those that were described in previous studies [11-14].

\section{Tissue microarray construction}

Tissue microarray was constructed from formalin-fixed, paraffinembedded breast cancer samples as previously described [11-14].

\section{Immunohistochemical methods}

Immunohistochemical staining of the tissue microarray slides followed previously described methods [11,12]. The immunohistochemical expression of the EMT biomarkers E- and P-cadherin was sought in the Nigerian breast cancer cases. The basal phenotype markers, Ki-67, p53 and BRCA1 were included to study their association with the cadherins. Positive and negative controls for each marker were included in the experiments. A proportion of UK grade-matched cases were used to compare the cadherin expression in the Nigerian series.

The E-cadherin was scored following the semi-quantitative Histochemical score (H-score) method which was described by McCarty et al. [15], where the intensity of staining and percentages of the stained cells were taken into consideration, with a minimum of zero and maximum of 300 scores. In addition, the scoring of the BRCA1, p53, Ki-67, other components of basal phenotype was as done in the previous studies [11-14].

\section{Statistical analyses}

Statistical Analyses was performed using SPSS version 16. The association between the cadherin markers expression and categorical clinicopathological variables was examined using the chi-square test. Analysis of survival characteristics of the cadherin biomarkers was analysed using Kaplan-Meier and Log-rank tests. Multivariate analysis was performed using Cox Regression Analysis. A two-sided P-value of $<0.05$ was considered to be statistically significant.

\section{Results}

\section{Staining characteristics of E- and P-cadherin}

The expressions of E- and P-cadherins were mainly detectable in the cytoplasm with some membranous staining of the invasive tumour cells (Figure 1). Based on the histogram distributions of scores, an $\mathrm{H}$-score of $\geq 100$ was taken as positive staining for E-cadherin, while a score of $\geq 10$ was considered positive for P-cadherin expression. Using these cut off points 66/226 (29.2\%) and $165 / 301(54.8 \%)$ of the Nigerian and UK breast cancer cases respectively showed positive expression of E-cadherin, while $142 / 266$ (53.4\%) and 138/261 (52.9\%) showed positive expression of P-cadherin in the Nigerian and UK cohorts respectively.

Clinicopathological and prognostic significance of E- and $P$-cadherin expression in the Nigerian versus the United Kingdom breast cancer cases

The expression of E- and P-cadherin was compared between the Nigerian breast cancer cohorts and their United Kingdom counterparts. The results showed that the UK cases significantly had more cases expressing E-cadherin than the Nigerian cohorts $(54.8 \%$ vs $29.2 \%$; $<0.001)$. However, there was no significant difference in $\mathrm{P}$-cadherin expression between the two cohorts.

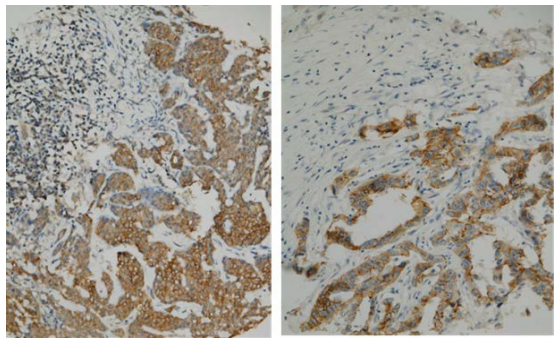

Figure 1: Photomicrograph of breast cancer section showing E-cadherin (A) and P-cadherin (B) immunoreactivity. Magnification x20.

Furthermore, while there was no significant association between the clinicopathological features and E-cadherin in the Nigerian cohorts, P-cadherin expression was significantly associated with menopausal status $(\mathrm{p}=0.04)$ and tumour tubular differentiation $(\mathrm{p}=0.02)$ (Tables 1 and 2).

In the UK series, the tumours that expressed E-cadherin were more of lobular histological type ( $<<0.001)$, were smaller than $2 \mathrm{~cm}$ in diameter $(\mathrm{p}<0.003)$, had reduced tendency for vascular invasion $(\mathrm{p}<$ 0.02 ) and better differentiated tubules compared to those with reduced or loss of E-cadherin expression $(\mathrm{p}<0.001)$. However, there was no significant correlation between the age of the women, menopausal status, lymph node involvement, vascular invasion, tumour size and E-cadherin expression (Table 1). P-cadherin-expressing tumours were more likely invasive ductal carcinoma NOS $(\mathrm{p}=0.02)$, had poorer tubule formation $(\mathrm{p}<0.001)$ and marked nuclear pleomorphism $(\mathrm{p}=$ 0.006 ) than tumours with reduced or no P-cadherin expression (Table 2).

E- and P-cadherin expression did not individually show any associations with breast cancer-specific survival (BCSS) or disease-free interval (DFI) in both the Nigerian and British cohorts (Figure 2).

\section{Relationship between E- and P-cadherin and other biomarker expression}

E-cadherin expression in the Nigerian breast cancer cohort did not show any associations with the tested biomarkers, including CK5/6, CK 14, EGFR, ER, PR, PIK3CA, p53, MUC1, BRCA1 and Ki-67 (Table 3). Furthermore, E-cadherin expression showed no association with P-cadherin $(\mathrm{p}=0.23)$. P-cadherin expression was associated with BRCA 1 loss $(\mathrm{p}=0.005)$, CK5/6 expression $(\mathrm{p}=0.007)$, EGFR expression (0.02), ER loss (0.004), PR loss $(\mathrm{p}=0.004)$, basal-like phenotype $(\mathrm{p}=$ $0.025)$, PIK3CA expression ( $\mathrm{p}=0.02), \mathrm{p} 53$ over-expression $(\mathrm{p}=0.01)$ and MUC1 expression $(\mathrm{p}=0.02)$ (Table 4$)$.

In the UK series, E-cadherin expression had a direct association with ER $(p=0.02)$ and HER2 $(p=0.03)$ expression and the Luminal A molecular subtype $(\mathrm{p}<0.001)$ of breast cancer and an inverse association with the triple-negative subtype $(\mathrm{p}=0.002)$ (Table 3$)$. $\mathrm{P}$-cadherin expression show significant direct associations with $\mathrm{CK}$ $5 / 6(\mathrm{p}<0.001)$, CK $14(\mathrm{p}=0.008)$ and EGFR $(\mathrm{p}<0.001)$ expression as well as basal-like $(\mathrm{p}<0.001)$ and triple-negative $(\mathrm{p}<0.001)$ breast cancer subtypes; and an inverse association with ER and PR expression. Like in the Nigerian series, P- and E-cadherin expression showed no association $(\mathrm{p}=0.58)($ Table 4$)$.

\section{E-cadherin and P-cadherin subsets revealed no new clinicopathological or biomarker expression information}

We hypothesized that stratifying the breast cancer cases into cadherin expression subsets (Ecad-low, Ecad-high, Pcad-low and 
Citation: Agboola AO, Ebili HO, lyawe VO, Banjo AAF, Salami BS, et al. (2016) Cadherin Expression in the Nigerian and United Kingdom Breast Cancer Cases: A Comparison of Clinicopathological and Prognostic Characteristics. Surgery Curr Res 6: 271. doi:10.4172/2161-1076.1000271

Page 3 of 8

\begin{tabular}{|c|c|c|c|c|c|c|c|c|c|}
\hline \multicolumn{5}{|c|}{ Nigerian BC cohort } & \multicolumn{5}{|c|}{ UK BC cohort } \\
\hline \multirow{2}{*}{ Variables } & \multicolumn{2}{|c|}{ E-cadherin expression } & \multirow{2}{*}{$X^{2}$ value } & \multirow{2}{*}{ p_value } & \multirow{2}{*}{ Variables } & \multicolumn{2}{|c|}{ E-cadherin expression } & \multirow{2}{*}{$X^{2}$ value } & \multirow{2}{*}{ p_value } \\
\hline & Negative & Positive & & & & Negative & Positive & & \\
\hline $\begin{array}{l}\text { Age (years) } \\
\leq 50 \\
>50\end{array}$ & $\begin{array}{c}106(66.7) \\
53(33.3)\end{array}$ & $\begin{array}{l}43(65.2) \\
23(34.8)\end{array}$ & 0.048 & 0.82 & $\begin{array}{l}\text { Age (years) } \\
\leq 50 \\
>50\end{array}$ & $\begin{array}{l}45(33.1) \\
91(66.9)\end{array}$ & $\begin{array}{r}51(31.1) \\
113(68.9)\end{array}$ & 0.135 & 0.713 \\
\hline $\begin{array}{l}\text { Menopausal } \\
\text { Pre } \\
\text { Post }\end{array}$ & $\begin{array}{l}111(69.8) \\
48(30.2)\end{array}$ & $\begin{array}{l}42(63.6) \\
24(36.4)\end{array}$ & 0.817 & 0.36 & $\begin{array}{l}\text { Menopausal } \\
\text { Pre } \\
\text { Post }\end{array}$ & $\begin{array}{l}53(39.0) \\
83(61.0)\end{array}$ & $\begin{array}{r}60(36.6) \\
104(63.4)\end{array}$ & 0.180 & 0.671 \\
\hline $\begin{array}{l}\text { Sizes }(\mathrm{cm}) \\
\leq 2 \\
>2\end{array}$ & $\begin{array}{c}12(7.5) \\
147(92.5)\end{array}$ & $\begin{array}{c}7(10.6) \\
59(89.4)\end{array}$ & 0.564 & 0.45 & $\begin{array}{l}\text { Sizes }(\mathrm{cm}) \\
\leq 2 \\
>2\end{array}$ & $\begin{array}{l}53(39.0) \\
83(61.0)\end{array}$ & $\begin{array}{l}93(56.4) \\
72(43.6)\end{array}$ & 9.029 & 0.003 \\
\hline $\begin{array}{l}\text { Lymph node } \\
\text { involvemeent } \\
\text { Negative } \\
\text { Positive }\end{array}$ & $\begin{array}{c}12(2.5) \\
147(92.5)\end{array}$ & $\begin{array}{c}5(7.6) \\
61(92.4)\end{array}$ & 0.001 & 0.99 & $\begin{array}{l}\text { Lymph node involvement } \\
\text { Negative } \\
\text { Positive }\end{array}$ & $\begin{array}{l}83(61.0) \\
53(39.0)\end{array}$ & $\begin{array}{l}97(58.8) \\
68(41.2)\end{array}$ & 0.156 & 0.693 \\
\hline $\begin{array}{l}\text { Vascular Invasion } \\
\text { Negative } \\
\text { Positive }\end{array}$ & $\begin{array}{l}126(79.2) \\
33(20.8)\end{array}$ & $\begin{array}{l}49(74.2) \\
17(25.8)\end{array}$ & 0.675 & 0.41 & $\begin{array}{l}\text { Vascular Invasion } \\
\text { Negative } \\
\text { Positive }\end{array}$ & $\begin{array}{l}50(36.8) \\
86(63.2)\end{array}$ & $\begin{array}{l}83(50.6) \\
81(49.4)\end{array}$ & 5.775 & 0.02 \\
\hline $\begin{array}{l}\text { Tumour Type } \\
\text { Typical medullary } \\
\text { Atypical medullary } \\
\text { Tubular } \\
\text { Lobular } \\
\text { Ductal /NST } \\
\text { Mucinous } \\
\text { Tubulolobular } \\
\text { Lobular mixed } \\
\text { Tubular mixed }\end{array}$ & $\begin{array}{c}0(0.0) \\
0(0.0) \\
2(1.3) \\
3(1.9) \\
134(84.3) \\
5(3.1) \\
1(0.6) \\
2(1.3) \\
12(7.5)\end{array}$ & $\begin{array}{c}6(1.5) \\
2(3.0) \\
0(0.0) \\
1(1.5) \\
60(90.9) \\
0(0.0) \\
0(0.0) \\
0(0.0) \\
2(3.0)\end{array}$ & 13.182 & 0.10 & $\begin{array}{l}\text { Tumour Type } \\
\text { Typical medullary Atypical } \\
\text { medullary } \\
\text { Tubular } \\
\text { Lobular } \\
\text { Ductal NST } \\
\text { Tubulolobular } \\
\text { Lobular mixed } \\
\text { Tubular mixed } \\
\text { Mixed NST } \\
\text { Others }\end{array}$ & $\begin{array}{c}6(4.5) \\
0(0.0) \\
32(25.4) \\
57(42.5) \\
1(0.7) \\
11(8.2) \\
11(8.2) \\
2(1.5) \\
9(6.7) \\
3(2.2)\end{array}$ & $\begin{array}{c}2(1.2) \\
3(1.8) \\
5(3.0) \\
113(68.9) \\
1(0.6) \\
3(1.8) \\
32(19.5) \\
0(0.0) \\
3(1.8) \\
2(1.2)\end{array}$ & 62.788 & $<0.001$ \\
\hline $\begin{array}{l}\text { Mitotic Figure } \\
\text { Low } \\
\text { Moderate } \\
\text { High }\end{array}$ & $\begin{array}{r}101(63.5) \\
37(23.3) \\
21(13.2)\end{array}$ & $\begin{array}{l}41(62.1) \\
13(19.7) \\
12(18.2)\end{array}$ & 1.069 & 0.58 & $\begin{array}{l}\text { Mitotic figure } \\
\text { Low } \\
\text { Moderate } \\
\text { High }\end{array}$ & $\begin{array}{l}57(42.9) \\
33(24.8) \\
43(32.3)\end{array}$ & $\begin{array}{l}56(33.9) \\
53(32.1) \\
56(33.9)\end{array}$ & 2.965 & 0.227 \\
\hline $\begin{array}{l}\text { Nuclear pleomorphism } \\
\text { Small regular uniform } \\
\text { cells }\end{array}$ & $1(0.6)$ & $0(0.0)$ & & & $\begin{array}{l}\text { Nuclear pleomorphism } \\
\text { Small regular uniform cells }\end{array}$ & $0(0.0)$ & $2(1.2)$ & & \\
\hline $\begin{array}{l}\text { Moderate increase in } \\
\text { size and variability }\end{array}$ & $58(36.5)$ & $22(33.3)$ & 0.649 & 0.72 & $\begin{array}{l}\text { Moderate increase in size } \\
\text { and variability }\end{array}$ & $74(55.6)$ & $66(40.0)$ & 8.374 & 0.02 \\
\hline Marked variability & $100(62.9)$ & $44(66.7)$ & & & Marked variability & $59(44.4)$ & $97(58.8)$ & & \\
\hline $\begin{array}{l}\text { Tubule Formation } \\
>75 \% \\
10-75 \% \\
<10 \%\end{array}$ & $\begin{aligned} 1(0.6) \\
8(5.0) \\
150(94.3)\end{aligned}$ & $\begin{array}{r}0(0.0) \\
4(6.1) \\
62(93.9)\end{array}$ & 0.509 & 0.77 & $\begin{array}{l}\text { Tubule Formation } \\
>75 \% \\
10-75 \% \\
<10 \%\end{array}$ & $\begin{array}{c}0(0.0) \\
28(21.1) \\
105(78.9)\end{array}$ & $\begin{array}{c}6(3.6) \\
71(43.6) \\
87(52.7)\end{array}$ & 23.887 & $<0.001$ \\
\hline
\end{tabular}

Table 1: Clinicopathological features of E-cadherin expression in Nigerian and UK BC cases.

Pcad-high) may show subset(s) with new clinicopathological and prognostic information in the Nigerian BC cases compared to their UK counterparts. However, in each of the subsets defined no new information was revealed with respect to the previously found difference in clinicopathological and molecular features between Nigerian and UK breast cancer cases. E- and P-cadherin expressions did not define clinically useful subsets of breast cancer cases.

\section{Discussion}

To the best of our knowledge this is the first study that has investigated the clinicopathological significance of the cadherin expression in Nigerian breast cancer cases in comparison to UK cases. While the $54.8 \% \mathrm{E}$-cadherin expression rate in the UK cases falls within the $46-75.3 \%$ rate that has been found in other studies, the $29.2 \%$ rate found in the Nigerian cohort is significantly lower [4-8,16]. This perhaps is a reflection of the fact that over $90 \%$ of the Nigerian breast cancer cases in this study are in the advance stage as adjudged by lymph node metastases. E-cadherin loss has previously been associated with advance stage breast cancer [8]. In contrast, the proportion of the UK cases in advance stage is only $40 \%$.
P-cadherin, on the other hand, is expressed in $20-71 \%$ of invasive breast cancer, within which the $52.9 \%$ and $53.4 \%$ rates we found for our cohorts fall $[1,3,9]$. We also found no association between the expressions of $\mathrm{E}$ - and $\mathrm{P}$-cadherin, an indication that their expressions do not have mutually exclusivity in breast cancer progression and that the cadherin switch includes intermediate states with complex expression patterns of the cadherins $[1,3,9]$.

E-cadherin loss in breast cancer has been associated with adverse clinicopathological characteristics in breast cancer from several populations studied [4-6]. We found this to be the case in our UK cohort of breast cancer in which E-cadherin loss was associated with larger tumours, increased tendency for vascular invasion and poor tubular differentiation. However, E-cadherin expression was not associated with any clinicopathological feature in the Nigerian breast cancer series, although the number of breast cancer cases with lymph node involvement, higher nuclear pleomorphism, larger size and poor tubular differentiation were higher in the E-cadherin-negative than the E-cadherin-positive groups. Similar to our finding, Brzozowska et al. and Younis et al. in their studies found no association between E-cadherin loss and clinicopathological indices [7,8]. It is worthy 
A

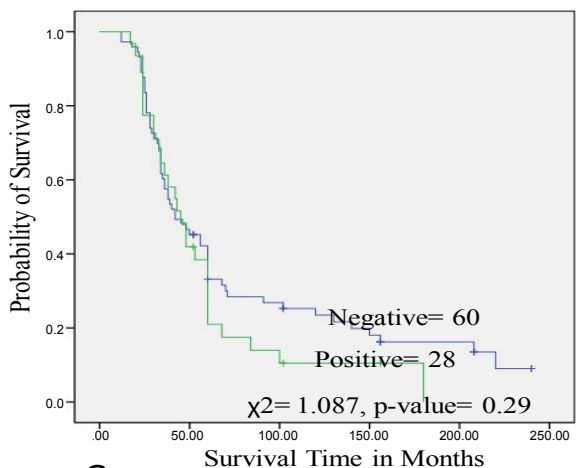

C

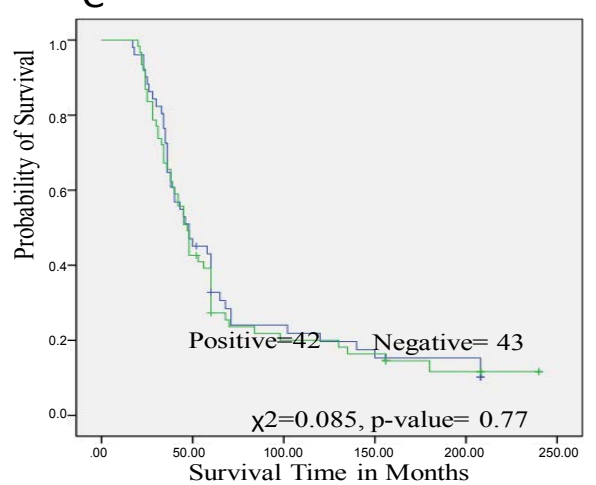

$\mathrm{E}$

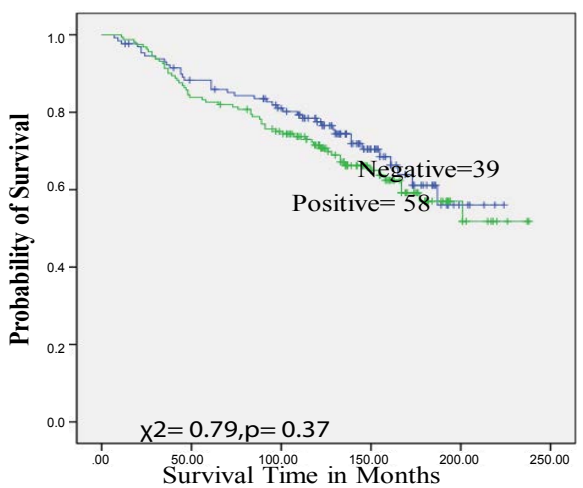

$\mathrm{G}$

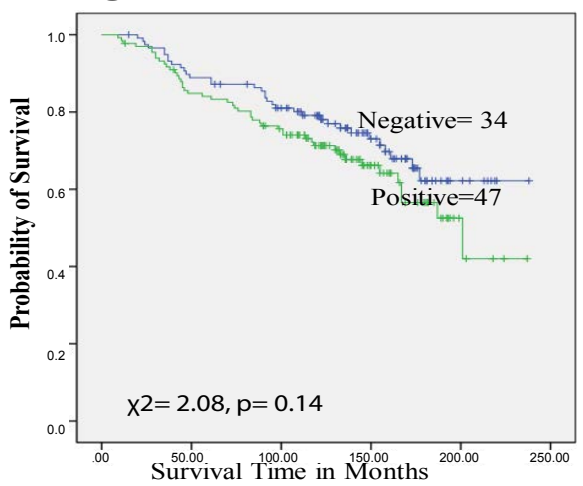

B
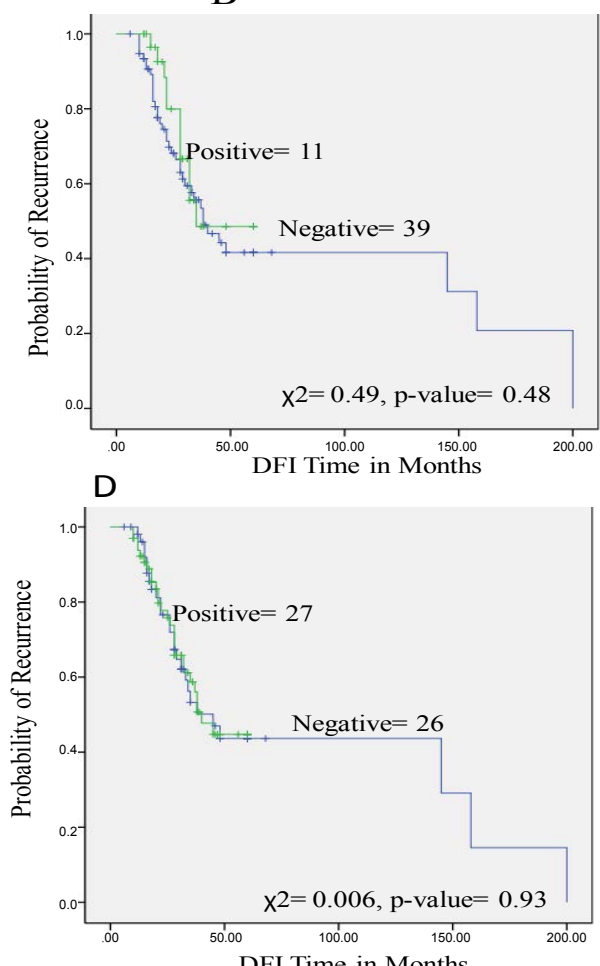

$\mathrm{F}$
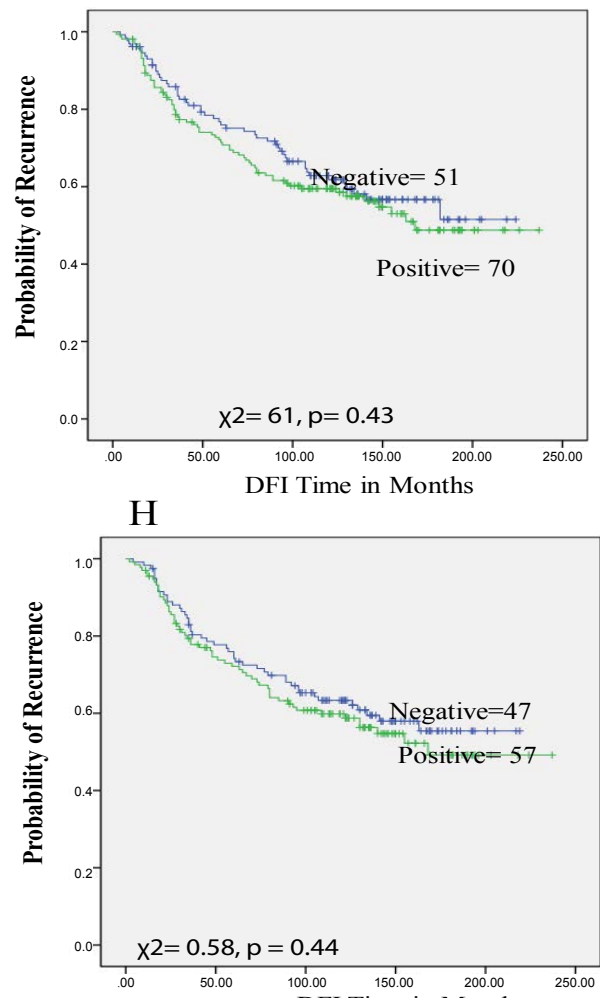

Figure 2: A and B. E-cadherin expression in relation to BCS and DFI in Nigeria series C and D. P-cadherin expression in relation to BCS and DFI in Nigeria series $\mathbf{E}$ and F. E-cadherin expression in relation to BCS and DFI in the UK series $\mathbf{G}$ and $\mathbf{H}$. P-cadherin expression in relation to BCS and DFI in in UK series. 
Citation: Agboola AO, Ebili HO, lyawe VO, Banjo AAF, Salami BS, et al. (2016) Cadherin Expression in the Nigerian and United Kingdom Breast Cancer Cases: A Comparison of Clinicopathological and Prognostic Characteristics. Surgery Curr Res 6: 271. doi:10.4172/2161-1076.1000271

Page 5 of 8

\begin{tabular}{|c|c|c|c|c|c|c|c|c|c|}
\hline \multicolumn{5}{|c|}{ Nigerian BC cohort } & \multicolumn{5}{|c|}{ UK BC cohort } \\
\hline \multirow{2}{*}{ Variables } & \multicolumn{2}{|c|}{ P-cadherin expression } & \multirow{2}{*}{$\mathrm{X}^{2}$ value } & \multirow{2}{*}{ p_value } & \multirow{2}{*}{ Variables } & \multicolumn{2}{|c|}{ P-cadherin expression } & \multirow{2}{*}{$X^{2}$ value } & \multirow{2}{*}{ p_value } \\
\hline & Negative & Positive & & & & Negative & Positive & & \\
\hline $\begin{array}{l}\text { Age (years) } \\
\quad \leq 50 \\
\quad>50\end{array}$ & $\begin{array}{l}65(63.7) \\
37(36.3)\end{array}$ & $\begin{array}{l}79(65.3) \\
42(34.7)\end{array}$ & 0.05 & 0.80 & $\begin{array}{l}\text { Age (years) } \\
\quad \leq 50 \\
\quad>50\end{array}$ & $\begin{array}{l}30(24.6) \\
92(75.4)\end{array}$ & $\begin{array}{l}54(39.1) \\
84(60.9)\end{array}$ & 6.26 & 0.01 \\
\hline $\begin{array}{l}\text { Menopausal } \\
\text { Pre } \\
\text { Post }\end{array}$ & $\begin{array}{l}63(61.8) \\
39(38.2)\end{array}$ & $\begin{array}{l}90(74.4) \\
31(25.6)\end{array}$ & 4.09 & 0.04 & $\begin{array}{l}\text { Menopausal } \\
\text { Pre } \\
\text { Post }\end{array}$ & $\begin{array}{l}42(34.4) \\
80(65.6)\end{array}$ & $\begin{array}{l}57(41.3) \\
81(58.7)\end{array}$ & 1.29 & 0.25 \\
\hline $\begin{array}{l}\text { Sizes }(\mathbf{c m}) \\
\quad \leq 2 \\
>2\end{array}$ & $\begin{array}{l}12(11.8) \\
90(88.2)\end{array}$ & $\begin{array}{c}7(5.8) \\
114(94.2)\end{array}$ & 2.53 & 0.11 & $\begin{array}{l}\text { Sizes }(\mathbf{c m}) \\
\quad \leq 2 \\
\quad>2\end{array}$ & $\begin{array}{l}64(52.0) \\
59(48.0)\end{array}$ & $\begin{array}{l}60(43.5) \\
78(56.5)\end{array}$ & 1.90 & 0.16 \\
\hline $\begin{array}{l}\text { Lymph node } \\
\text { involvemeent } \\
\text { Negative } \\
\text { Positive }\end{array}$ & $\begin{array}{l}12(11.8) \\
90(88.2)\end{array}$ & $\begin{array}{c}9(7.4) \\
112(92.6)\end{array}$ & 1.21 & 0.27 & $\begin{array}{c}\text { Lymph node involvement } \\
\text { Negative } \\
\text { Positive }\end{array}$ & $\begin{array}{l}72(58.5) \\
51(41.5)\end{array}$ & $\begin{array}{l}82(59.4) \\
56(40.6)\end{array}$ & 0.02 & 0.88 \\
\hline $\begin{array}{l}\text { Vascular Invasion } \\
\text { Negative } \\
\text { Positive }\end{array}$ & $\begin{array}{l}73(71.6) \\
29(28.4)\end{array}$ & $\begin{array}{l}91(75.2) \\
30(24.8)\end{array}$ & 0.37 & 0.54 & $\begin{array}{l}\text { Vascular Invasion } \\
\text { Negative } \\
\text { Positive }\end{array}$ & $\begin{array}{l}58(47.5) \\
64(52.5)\end{array}$ & $\begin{array}{l}58(42.0) \\
80(58.0)\end{array}$ & 0.79 & 0.37 \\
\hline $\begin{array}{c}\text { Tumour Type } \\
\text { Atypical medullary } \\
\text { Tubular } \\
\text { Lobular } \\
\text { Ductal /NST } \\
\text { Mucinous } \\
\text { Tubulolobular } \\
\text { Lobular mixed } \\
\text { Tubular mixed } \\
\text { Mixed NST } \\
\text { Others }\end{array}$ & $\begin{array}{c}1(1.0) \\
1(1.0) \\
2(2.0) \\
88(86.3) \\
3(2.9) \\
1(1.0) \\
0(0.0) \\
6(5.9) \\
0(0.0) \\
0(0.0)\end{array}$ & $\begin{array}{c}1(0.8) \\
1(0.8) \\
1(0.8) \\
109(90.1) \\
0(0.0) \\
0(0.0) \\
3(2.5) \\
6(5.0) \\
0(0.0) \\
0(0.0)\end{array}$ & 8.01 & 0.33 & $\begin{array}{c}\text { Tumour Type } \\
\text { Atypical medullary } \\
\text { Tubular } \\
\text { Lobular } \\
\text { Ductal NST } \\
\text { Mucinous } \\
\text { Tubulolobular } \\
\text { Lobular mixed } \\
\text { Tubular mixed } \\
\text { Mixed NST } \\
\text { Others }\end{array}$ & $\begin{aligned} 1 & (0.8) \\
3 & (2.5) \\
22 & (18.0) \\
61 & (50.0) \\
1 & (0.8) \\
6 & (4.9) \\
18 & (14.8) \\
1 & (0.8) \\
7 & (5.7) \\
0 & (0.0)\end{aligned}$ & $\begin{array}{c}7(5.1) \\
0(0.0) \\
10(7.2) \\
91(65.9) \\
1(0.7) \\
5(3.6) \\
17(12.3) \\
1(0.7) \\
4(2.9) \\
2(1.4)\end{array}$ & 21.95 & 0.02 \\
\hline $\begin{array}{l}\text { Mitotic Figure } \\
\text { Low } \\
\text { Moderate } \\
\text { High }\end{array}$ & $\begin{array}{l}66(64.7) \\
24(23.5) \\
12(11.8)\end{array}$ & $\begin{array}{l}75(62.0) \\
24(19.8) \\
22(18.2)\end{array}$ & 1.91 & 0.38 & $\begin{array}{c}\text { Mitotic figure } \\
\text { Low } \\
\text { Moderate } \\
\text { High }\end{array}$ & $\begin{array}{r}4(3.3) \\
45(37.2) \\
72(59.5)\end{array}$ & $\begin{array}{r}2(1.5) \\
41(29.9) \\
94(68.6)\end{array}$ & 2.787 & 0.248 \\
\hline $\begin{array}{l}\text { Nuclear pleomorphism } \\
\text { Small regular uniform } \\
\text { cells } \\
\text { Moderate increase in } \\
\text { size and variability }\end{array}$ & $37(36.3)$ & $0(0.0)$ & 0.81 & 0.36 & $\begin{array}{l}\text { Nuclear pleomorphism } \\
\text { Small regular uniform cells } \\
\begin{array}{c}\text { Moderate increase in size } \\
\text { and variability }\end{array}\end{array}$ & $\begin{array}{r}2(1.7) \\
66(54.6)\end{array}$ & $\begin{array}{c}0(0.0) \\
52(38.0)\end{array}$ & 10.128 & 0.006 \\
\hline Marked variability & $65(63.7)$ & $84(68.4)$ & & & Marked variability & $53(43.8)$ & $85(62.0)$ & & \\
\hline $\begin{array}{c}\text { Tubule Formation } \\
>75 \% \\
10-75 \% \\
<10 \%\end{array}$ & $\begin{array}{c}0(0.0) \\
1(1.0) \\
101(99.0)\end{array}$ & $\begin{array}{c}2(2.5) \\
9(7.4) \\
108(90.1)\end{array}$ & 8.14 & 0.02 & $\begin{array}{c}\text { Tubule Formation } \\
>75 \% \\
10-75 \% \\
<10 \% \\
\end{array}$ & $\begin{array}{l}56(46.3) \\
37(30.6) \\
28(23.1)\end{array}$ & $\begin{array}{l}40(29.2) \\
32(23.4) \\
65(47.4)\end{array}$ & 16.822 & $<0.001$ \\
\hline
\end{tabular}

Table 2: Clinicopathological features of P-cadherin expression in Nigerian and UK BC cases.

of note that the cohorts used in the aforementioned studies, like our Nigerian cohort, had disproportionate amounts of E-cadherin-positive cases $-75.3 \%$ and $72 \%$ respectively- and small sample sizes; and these could have precluded meaningful statistical analyses and obscured the actual significance of E-cadherin loss in these BC populations.

P-cadherin expression, on the other hand, was found to be associated with features of high tumour grades in both the Nigerian and UK breast cancer cohorts; and with and postmenopausal status in the Nigeria cohort and invasive ductal carcinoma NOS in the UK cohort. P-cadherin expression has similarly been reported by other studies to show an association with high tumour grades, age at diagnosis and tumour histological subtype $[1,3,9]$. Other clinicopathological indices which have been shown to correlate with P-cadherin expression but which we did not find in either of our breast cancer cohorts include lymph node metastases $[1,3,9]$.

With respect to biomarker expression, while E-cadherin expression showed no association with any of the biomarker tested in the Nigerian cohort, it shows associations with ER and HER2 expression and the
Luminal A and the triple-negative molecular subtype of breast cancer in the UK breast cancer series. The association between breast cancer subtypes biomarkers and E-cadherin expression in the UK cohort is in concordance findings in other studies, but contrasts with the absence of any associations in the Nigerian series, as well as the Brzozowska et al. and Younis et al. studies [5,7,8]. This lack of patholobiological significance of E-cadherin expression in the Nigerian series may represent another difference in tumour biology between Nigerian and UK breast cancer cases. On the other hand, it may be reflective of the disproportionate representation of E-cadherin-positive tumor in the Nigerian cohort (only 29\%) used in this study. Further studies in which E-cadherin-positive and -negative are about equally represented in the sample cohort are probably needed to clarify the significance of E-cadherin expression in the Nigerian breast cancer cases.

P-cadherin expression has been associated with the features of basal-like subtype of breast cancer, including ER loss, PR loss, EGFR expression and CK 5/6 and CK14 expression, p53 over-expression 
Citation: Agboola AO, Ebili HO, lyawe VO, Banjo AAF, Salami BS, et al. (2016) Cadherin Expression in the Nigerian and United Kingdom Breast Cancer Cases: A Comparison of Clinicopathological and Prognostic Characteristics. Surgery Curr Res 6: 271. doi:10.4172/2161-1076.1000271

Page 6 of 8

\begin{tabular}{|c|c|c|c|c|c|c|c|c|c|}
\hline \multicolumn{5}{|c|}{ Nigerian BC cohort } & \multicolumn{5}{|c|}{ UK BC cohort } \\
\hline \multirow{2}{*}{ Variables } & \multicolumn{2}{|c|}{ E-cadherin expression } & \multirow{2}{*}{$X^{2}$ value } & \multirow{2}{*}{ p_value } & \multirow{2}{*}{ Variables } & \multicolumn{2}{|c|}{ E-cadherin expression } & \multirow{2}{*}{$X^{2}$ value } & \multirow{2}{*}{ p_value } \\
\hline & Negative & Positive & & & & Negative & Positive & & \\
\hline $\begin{array}{c}\text { BRCA1 } \\
\text { Negative } \\
\text { Positive }\end{array}$ & $\begin{array}{c}104(81.9) \\
23(18.1)\end{array}$ & $\begin{array}{l}37(68.5) \\
17(31.5)\end{array}$ & 3.93 & 0.05 & $\begin{array}{l}\text { BRCA1 } \\
\text { Negative } \\
\text { Positive }\end{array}$ & $\begin{array}{l}23(20.0) \\
92(80.0)\end{array}$ & $\begin{array}{c}20(14.4) \\
119(85.6)\end{array}$ & 1.409 & 0.235 \\
\hline $\begin{array}{c}\text { CK5/6 } \\
\text { Negative } \\
\text { Positive }\end{array}$ & $\begin{array}{l}85(63.4) \\
49(36.6)\end{array}$ & $\begin{array}{l}29(55.8) \\
23(44.2)\end{array}$ & 0.92 & 0.33 & $\begin{array}{l}\text { CK5/6 } \\
\text { Negative } \\
\text { Positive }\end{array}$ & $\begin{array}{c}116(86.6) \\
18(13.4)\end{array}$ & $\begin{array}{c}147(89.6) \\
17(10.4)\end{array}$ & 0.669 & 0.413 \\
\hline $\begin{array}{l}\text { CK14 } \\
\text { Negative } \\
\text { Positive }\end{array}$ & $\begin{array}{l}76(58.9) \\
53(41.1)\end{array}$ & $\begin{array}{l}32(60.4) \\
21(39.6)\end{array}$ & 0.03 & 0.85 & $\begin{array}{c}\text { CK14 } \\
\text { Negative } \\
\text { Positive }\end{array}$ & $\begin{array}{r}119(91.5) \\
11(8.5)\end{array}$ & $\begin{array}{c}150(92.0) \\
13(8.0)\end{array}$ & 0.023 & 0.880 \\
\hline $\begin{array}{c}\text { Classification } \\
\text { Basal } \\
\text { HER-2 } \\
\text { Lum A } \\
\text { Lum B } \\
\text { Uncl }\end{array}$ & $\begin{array}{c}32(20.1) \\
20(12.6) \\
28(17.6) \\
5(3.1) \\
14(8.8)\end{array}$ & $\begin{array}{c}18(27.3) \\
11(16.7) \\
12(18.2) \\
3(4.5) \\
6(9.1)\end{array}$ & 4.42 & 0.49 & $\begin{array}{c}\text { Classification } \\
\text { Basal } \\
\text { HER-2 } \\
\text { Lum A } \\
\text { Lum B } \\
\text { Uncl }\end{array}$ & $\begin{array}{c}15(11.3) \\
5(5) \\
97(72.9) \\
3(2.3) \\
13(9.8)\end{array}$ & $\begin{array}{r}12(7.5) \\
9(5.6) \\
125(78.1) \\
13(8.1) \\
1(0.6)\end{array}$ & 19.21 & $<0.001$ \\
\hline $\begin{array}{c}\text { ER } \\
\text { Negative } \\
\text { Positive }\end{array}$ & $\begin{array}{c}110(75.3) \\
36(24.7)\end{array}$ & $\begin{array}{l}43(69.4) \\
19(30.6)\end{array}$ & 0.80 & 0.37 & $\begin{array}{c}\text { ER } \\
\text { Negative } \\
\text { Positive }\end{array}$ & $\begin{array}{r}35(25.9) \\
100(74.1)\end{array}$ & $\begin{array}{r}24(14.7) \\
139(85.3)\end{array}$ & 5.83 & 0.02 \\
\hline $\begin{array}{c}\text { EGFR } \\
\text { Negative } \\
\text { Positive }\end{array}$ & $\begin{array}{l}88(68.8) \\
40(31.2)\end{array}$ & $\begin{array}{l}30(62.5) \\
18(37.5)\end{array}$ & 0.61 & 0.43 & $\begin{array}{c}\text { EGFR } \\
\text { Negative } \\
\text { Positive }\end{array}$ & $\begin{array}{r}105(86.8) \\
16(13.2)\end{array}$ & $\begin{array}{r}121(80.1) \\
30(19.9)\end{array}$ & 2.11 & 0.14 \\
\hline $\begin{array}{c}\text { HER_2 } \\
\text { Negative } \\
\text { Positive }\end{array}$ & $\begin{array}{c}116(81.7) \\
26(18.3)\end{array}$ & $\begin{array}{l}45(73.8) \\
16(26.2)\end{array}$ & 1.63 & 0.20 & $\begin{array}{l}\text { HER_2 } \\
\text { Negative } \\
\text { Positive }\end{array}$ & $\begin{array}{c}127(94.1) \\
8(5.9)\end{array}$ & $\begin{array}{l}141(86.5) \\
22(13.5)\end{array}$ & 4.67 & 0.03 \\
\hline $\begin{array}{c}\text { KI_67 } \\
\text { Negative } \\
\text { Positive }\end{array}$ & $\begin{array}{c}20(14.5) \\
118(85.5)\end{array}$ & $\begin{array}{l}14(24.6) \\
43(75.4)\end{array}$ & 2.84 & 0.09 & $\begin{array}{c}\text { KI_67 } \\
\text { Negative } \\
\text { Positive }\end{array}$ & $\begin{array}{l}40(38.1) \\
65(61.9)\end{array}$ & $\begin{array}{l}42(30.2) \\
97(69.8)\end{array}$ & 1.66 & 0.19 \\
\hline $\begin{array}{c}\text { Mucin1 } \\
\text { Negative } \\
\text { Positive }\end{array}$ & $\begin{array}{l}60(48.4) \\
64(51.6)\end{array}$ & $\begin{array}{l}22(47.8) \\
24(52.2)\end{array}$ & 0.004 & 0.94 & $\begin{array}{l}\text { Mucin1 } \\
\text { Negative } \\
\text { Positive }\end{array}$ & $\begin{array}{c}15(12.7) \\
103(87.3)\end{array}$ & $\begin{array}{c}12(8.9) \\
123(91.1)\end{array}$ & 0.96 & 0.33 \\
\hline $\begin{array}{l}\text { P_cad } \\
\text { Negative } \\
\text { Positive }\end{array}$ & & & & & $\begin{array}{l}\text { P_cad } \\
\text { Negative } \\
\text { Positive }\end{array}$ & $\begin{array}{l}52(45.2) \\
63(54.8)\end{array}$ & $\begin{array}{l}71(48.6) \\
75(51.4)\end{array}$ & 0.30 & 0.58 \\
\hline $\begin{array}{c}\text { PGR } \\
\text { Negative } \\
\text { Positive }\end{array}$ & $\begin{array}{l}95(76.0) \\
30(24.0)\end{array}$ & $\begin{array}{l}42(75.0) \\
14(25.0)\end{array}$ & 0.02 & 0.88 & $\begin{array}{c}\text { PGR } \\
\text { Negative } \\
\text { Positive }\end{array}$ & $\begin{array}{l}54(40.0) \\
81(60.0)\end{array}$ & $\begin{array}{c}62(37.8) \\
102(62.2)\end{array}$ & 0.15 & 0.69 \\
\hline $\begin{array}{c}\text { p53 } \\
\text { Negative } \\
\text { Positive }\end{array}$ & $\begin{array}{l}40(34.8) \\
75(65.2)\end{array}$ & $\begin{array}{l}22(37.3) \\
37(62.7)\end{array}$ & 0.10 & 0.74 & $\begin{array}{c}\text { p53 } \\
\text { Negative } \\
\text { Positive }\end{array}$ & $\begin{array}{r}104(77.0) \\
31(23.0)\end{array}$ & $\begin{array}{r}117(72.2) \\
45(27.8)\end{array}$ & 0.89 & 0.34 \\
\hline $\begin{array}{c}\text { Triple Negative } \\
\text { No } \\
\text { Yes }\end{array}$ & $\begin{array}{l}61(50.4) \\
60(49.0)\end{array}$ & $\begin{array}{l}33(55.0) \\
27(45.0)\end{array}$ & 0.33 & 0.56 & $\begin{array}{c}\text { Triple Negative } \\
\text { No } \\
\text { Yes }\end{array}$ & $\begin{array}{c}106(78.5) \\
29(21.5)\end{array}$ & $\begin{array}{c}150(91.5) \\
14(8.5)\end{array}$ & 10.07 & 0.002 \\
\hline
\end{tabular}

Table 3: Correlation E-cadherin and other biomarker expression in Nigerian and UK BC cases.

and BRCA1 loss $[1,3]$. Furthermore, it has been demonstrated that P-cadherin expression is a more sensitive marker for the basal-like breast cancer subtype than CK 5/6 and EGFR [3]. In line with the strong association between P-cadherin and basal-like breast cancer subtype this study demonstrated an association between the basal-like breast cancer and ER and PR loss, CK 5/6, CK14, p53 and EGFR expression in both the Nigerian and UK breast cancer cohorts. Furthermore, we demonstrated that P-cadherin was associated with BRCA1 loss in the Nigerian, but not in the UK, breast cancer cohort. This is probably due to the significantly higher rate of BRCA 1-deficient basal-like cancer in the Nigerian cohort relative to the UK cases [11,17].

P-cadherin has also been associated with the invasive potentials of breast cancer. For example, P-cadherin has been demonstrated to induce increased motility and invasiveness of breast cancer cells in association with the epithelial mesenchymal transition $[1,3,9]$. In this study we showed an association between P-cadherin and MUC1 expression, in the Nigerian series, but not in the UK cohort. Schroeder et al. reported that MUC1 expression is associated with breast cancer cell invasion and metastasis. In that study it was shown that MUC1interacts with $\beta$-catenin both in vitro and in clinical breast cancer to promote cell invasion and metastases [18]. The association between P-cadherin and MUC1 expressions in the Nigerian cohort suggests that MUC1 expression may be important in cellular invasion and metastases in at least a subset of P-cadherin-positive Nigerian breast cancer cohort.

In contrast to many other studies, we did not find any prognostic significance for both E-cadherin and P-cadherin expression either in the Nigerian or the UK cases [1,3,5-7,9]. Furthermore, we did not find any association between prognostic marker Ki-67 and either P-cadherin or E-cadherin in both breast cancer populations [12].

The high rate of P-cadherin expression in both breast cancer populations may have therapeutic significance. Albergaria et al. showed that P-cadherin silencing in breast cancer cells inoculated in mice inhibited the growth of cancer in vivo [3]. Furthermore, a novel and highly selective human monoclonal antibody (PF-03732010) has been developed against $\mathrm{P}$-cadherin and has demonstrated remarkable antitumour and anti-metastatic activities against P-cadherin-expressing tumours in preclinical trials [19]. Such therapy may be especially important in the triple-negative breast cancer subtype which currently lack targeted therapy. 
Citation: Agboola AO, Ebili HO, lyawe VO, Banjo AAF, Salami BS, et al. (2016) Cadherin Expression in the Nigerian and United Kingdom Breast Cancer Cases: A Comparison of Clinicopathological and Prognostic Characteristics. Surgery Curr Res 6: 271. doi:10.4172/2161-1076.1000271

Page 7 of 8

\begin{tabular}{|c|c|c|c|c|c|c|c|c|c|}
\hline \multicolumn{5}{|c|}{ Nigerian BC cohort } & \multicolumn{5}{|c|}{ UK BC cohort } \\
\hline \multirow{2}{*}{ Variables } & \multicolumn{2}{|c|}{ P-cadherin expression } & \multirow{2}{*}{$X^{2}$ value } & \multirow{2}{*}{ p_value } & \multirow{2}{*}{ Variables } & \multicolumn{2}{|c|}{ P-cadherin expression } & \multirow{2}{*}{$X^{2}$ value } & \multirow{2}{*}{ p_value } \\
\hline & Negative & Positive & & & & Negative & Positive & & \\
\hline $\begin{array}{c}\text { BRCA1 } \\
\text { Negative } \\
\text { Positive }\end{array}$ & $\begin{array}{l}53(70.7) \\
22(29.3)\end{array}$ & $\begin{array}{l}91(87.5) \\
13(12.5)\end{array}$ & 7.85 & 0.005 & $\begin{array}{l}\text { BRCA1 } \\
\text { Negative } \\
\text { Positive }\end{array}$ & $\begin{array}{l}18(16.4) \\
92(83.6)\end{array}$ & $\begin{array}{r}24(18.3) \\
107(81.7)\end{array}$ & 0.15 & 0.69 \\
\hline $\begin{array}{l}\text { CK5/6 } \\
\text { Negative } \\
\text { Positive }\end{array}$ & $\begin{array}{l}58(68.2) \\
27(31.8)\end{array}$ & $\begin{array}{l}54(49.1) \\
56(50.9)\end{array}$ & 7.18 & 0.007 & $\begin{array}{l}\text { CK5/6 } \\
\text { Negative } \\
\text { Positive }\end{array}$ & $\begin{array}{r}118(97.5) \\
3(2.5)\end{array}$ & $\begin{array}{r}113(81.9) \\
25(18.1)\end{array}$ & 16.34 & $<0.001$ \\
\hline $\begin{array}{l}\text { CK14 } \\
\text { Negative } \\
\text { Positive }\end{array}$ & $\begin{array}{l}36(51.4) \\
34(48.6)\end{array}$ & $\begin{array}{l}59(59.6) \\
40(40.4)\end{array}$ & 1.11 & 0.29 & $\begin{array}{l}\text { CK14 } \\
\text { Negative } \\
\text { Positive }\end{array}$ & $\begin{array}{r}117(96.7) \\
4(3.3)\end{array}$ & $\begin{array}{r}120(87.6) \\
17(12.4)\end{array}$ & 7.12 & 0.008 \\
\hline $\begin{array}{c}\text { Classification } \\
\text { Basal } \\
\text { HER-2 } \\
\text { Lum A } \\
\text { Lum B } \\
\text { Uncl }\end{array}$ & $\begin{array}{c}18(17.6) \\
9(8.8) \\
21(20.8) \\
5(4.9)\end{array}$ & $\begin{array}{c}40(33.1) \\
15(12.4) \\
17(14.0) \\
2(1.7)\end{array}$ & 10.07 & 0.07 & $\begin{array}{c}\text { Classification } \\
\text { Basal } \\
\text { HER-2 } \\
\text { Lum A } \\
\text { Lum B } \\
\text { Uncl }\end{array}$ & $\begin{array}{r}1(0.8) \\
2(1.7) \\
107(88.4) \\
8(6.6)\end{array}$ & $\begin{array}{r}26(19.1) \\
8(5.9) \\
86(63.2) \\
5(3.7)\end{array}$ & 33.53 & $<0.001$ \\
\hline $\begin{array}{c}\text { ER } \\
\text { Negative } \\
\text { Positive }\end{array}$ & $\begin{array}{l}57(63.3) \\
33(36.7)\end{array}$ & $\begin{array}{l}91(81.3) \\
21(18.7)\end{array}$ & 8.20 & 0.004 & $\begin{array}{c}\text { ER } \\
\text { Negative } \\
\text { Positive }\end{array}$ & $\begin{array}{c}6(4.9) \\
116(95.1)\end{array}$ & $\begin{array}{l}47(34.3) \\
90(65.7)\end{array}$ & 34.24 & $<0.001$ \\
\hline $\begin{array}{l}\text { EGFR } \\
\text { Negative } \\
\text { Positive }\end{array}$ & $\begin{array}{l}58(76.3) \\
18(23.7)\end{array}$ & $\begin{array}{l}60(59.4) \\
41(40.6)\end{array}$ & 5.5 & 0.02 & $\begin{array}{l}\text { EGFR } \\
\text { Negative } \\
\text { Positive }\end{array}$ & $\begin{array}{c}109(90.8) \\
11(9.2)\end{array}$ & $\begin{array}{r}108(78.3) \\
30(21.7)\end{array}$ & 7.59 & 0.006 \\
\hline $\begin{array}{c}\text { HER_2 } \\
\text { Negative } \\
\text { Positive }\end{array}$ & $\begin{array}{l}71(83.5) \\
14(16.5)\end{array}$ & $\begin{array}{l}82(79.6) \\
21(20.4)\end{array}$ & 0.47 & 0.49 & $\begin{array}{l}\text { HER_2 } \\
\text { Negative } \\
\text { Positive }\end{array}$ & $\begin{array}{c}112(91.8) \\
10(8.2)\end{array}$ & $\begin{array}{c}124(90.5) \\
13(9.5)\end{array}$ & 0.13 & 0.71 \\
\hline $\begin{array}{l}\text { KI_67 } \\
\text { Negative } \\
\text { Positive }\end{array}$ & $\begin{array}{l}19(22.4) \\
66(77.6)\end{array}$ & $\begin{array}{l}17(15.2) \\
95(84.8)\end{array}$ & 1.66 & 0.19 & $\begin{array}{l}\text { KI_67 } \\
\text { Negative } \\
\text { Positive }\end{array}$ & $\begin{array}{l}32(32.7) \\
66(67.3)\end{array}$ & $\begin{array}{l}33(28.9) \\
81(71.1)\end{array}$ & 0.34 & 0.56 \\
\hline $\begin{array}{l}\text { Mucin1 } \\
\text { Negative } \\
\text { Positive }\end{array}$ & $\begin{array}{l}44(57.1) \\
33(42,9)\end{array}$ & $\begin{array}{l}39(39.4) \\
60(60.6)\end{array}$ & 5.50 & 0.02 & $\begin{array}{l}\text { Mucin1 } \\
\text { Negative } \\
\text { Positive }\end{array}$ & $\begin{array}{r}9(8.0) \\
104(92.0)\end{array}$ & $\begin{array}{r}17(13.3) \\
111(86.7)\end{array}$ & 1.76 & 0.18 \\
\hline $\begin{array}{l}\text { E_cad } \\
\text { Negative } \\
\text { Positive }\end{array}$ & $\begin{array}{l}57(74.0) \\
20(26.0)\end{array}$ & $\begin{array}{l}57(65.5) \\
30(34.5)\end{array}$ & 1.395 & 0.23 & $\begin{array}{l}\text { E_cad } \\
\text { Negative } \\
\text { Positive }\end{array}$ & $\begin{array}{l}52(42.3) \\
71(57.7)\end{array}$ & $\begin{array}{l}63(45.7) \\
75(54.3)\end{array}$ & 0.30 & 0.58 \\
\hline $\begin{array}{l}\text { PGR } \\
\text { Negative } \\
\text { Positive }\end{array}$ & $\begin{array}{l}53(66.3) \\
27(33.7)\end{array}$ & $\begin{array}{l}83(84.7) \\
15(15.3)\end{array}$ & 8.31 & 0.004 & $\begin{array}{c}\text { PGR } \\
\text { Negative } \\
\text { Positive }\end{array}$ & $\begin{array}{l}32(26.0) \\
91(74.0)\end{array}$ & $\begin{array}{l}71(51.8) \\
66(48.2)\end{array}$ & 18.04 & $<0.001$ \\
\hline $\begin{array}{c}\text { p53 } \\
\text { Negative } \\
\text { Positive }\end{array}$ & $\begin{array}{l}29(43.3) \\
38(56.7)\end{array}$ & $\begin{array}{l}24(24.7) \\
73(75.3)\end{array}$ & 6.22 & 0.01 & $\begin{array}{c}\text { p53 } \\
\text { Negative } \\
\text { Positive }\end{array}$ & $\begin{array}{r}108(90.0) \\
12(10.0)\end{array}$ & $\begin{array}{l}83(60.1) \\
55(39.9)\end{array}$ & 29.75 & $<0.001$ \\
\hline $\begin{array}{c}\text { Triple Negative } \\
\text { No } \\
\text { Yes }\end{array}$ & $\begin{array}{l}45(56.3) \\
35(43.7)\end{array}$ & $\begin{array}{l}41(44.6) \\
51(55.4)\end{array}$ & 2.34 & 0.13 & $\begin{array}{c}\text { Triple Negative } \\
\text { No } \\
\text { Yes }\end{array}$ & $\begin{array}{r}118(96.7) \\
4(3.3)\end{array}$ & $\begin{array}{r}101(73.2) \\
37(26.8)\end{array}$ & 26.99 & $<0.001$ \\
\hline
\end{tabular}

Table 4: Correlation P-cadherin and other biomarker expression in Nigerian and UK BC cases.

In conclusion, we have shown for the first time that while P-cadherin is associated with the basal-like breast cancer in both Nigerian and UK breast cancer cases, E-cadherin expression was associated with the luminal A and HER2 breast cancer subtypes in the UK cases but showed no pathobiological significance in the Nigerian cohorts.

\section{Acknowledgement}

The authors wish to acknowledge the efforts of the technical staff of the Histopathology Department, Olabisi Onabanjo University Teaching Hospital Sagamu, Nigeria, and University of Nottingham City Hospital towards the completion of this study.

\section{References}

1. Ribeiro AS, Paredes J (2015) P-cadherin linking breast cancer stem cells and invasion: a promising marker to identify an "Intermediate/Metastable" EMT state. Front Oncol 4: 371

2. Derycke LDM, Bracke ME (2004) N-cadherin in the spotlight of cell-cell adhesion, differentiation, embryogenesis, invasion and signalling. Int $\mathrm{J}$ Dev Biol 48: 463-476.

3. Albergaria A, Ribeiro AS, Vieira AF, Souse B, Nobre AR, et al. (2011) P-cadherin role in normal breast development and cancer. Int J Dev Biol 55: 811-822.
4. Suciu C, Cîmpean AM, Mureşan AM , Izvernariu D, Raica M (2008) E-cadherin expression in invasive breast cancer. Romanian Journal of Morphology and Embryology 49: 517-523.

5. Kashiwagi S, Yashiro M, Takashima T, Nomura S, Noda S, et al. (2010) Significance of E-cadherin expression in triple-negative breast cancer. $\mathrm{Br} J$ Cancer 103: 249-255.

6. Berx G, Roy FV (2001) The E-cadherin/catenin complex: an important gatekeeper in breast cancer tumorigenesis and malignant progression. Breast Cancer Res 3: 289-293.

7. Brzozowska A, Sodolski T, Duma D, Mazurkiewicz T, Mazurkiewicz M (2012) Evaluation of prognostic parameters of E-cadherin status in breast cancer treatment. Ann Agric Environ Med. 19: 541-546.

8. Younis LK, El Sakka H, Haque I (2007) The Prognostic Value of E-cadherin Expression in Breast Cancer. Int J Health Sci 1: 43-51.

9. Paredes J, Correia AL, Ribeiro AS, Albergaria A, Milanezi F, et al. (2007) P-cadherin expression in breast cancer: a review. Breast Cancer Res 9 : 214

10. McShane LM, Altman DG, Sauerbrei W, Taube SE, Gion M, et al. (2005) Reporting recommendations for tumor marker prognostic studies. J Clin Oncol 23: 9067-9072. 
Citation: Agboola AO, Ebili HO, Iyawe VO, Banjo AAF, Salami BS, et al. (2016) Cadherin Expression in the Nigerian and United Kingdom Breast Cancer Cases: A Comparison of Clinicopathological and Prognostic Characteristics. Surgery Curr Res 6: 271. doi:10.4172/2161-1076.1000271

11. Agboola AJ, Musa AA, Wanangwa N, Abdel-Fatah T, Nolan CC, et al. (2012) Molecular characteristics and prognostic features of breast cancer in Nigerian compared with UK women. Breast Cancer Res Treat 135: 555-569.

12. Agboola AOJ, Banjo AAF, Anunobi CC, Salami B, Agboola MD, Musa AA et al. (2013) Cell Proliferation (KI-67) Expression Is Associated with Poorer Prognosis in Nigerian Compared to British Breast Cancer Women. ISRN Onco

13. Agboola AOJ, Banjo AAF, Anunobi CC, Ayoade BA, Deji-Agboola MA, et al (2013) Clinical and molecular significance of poly (ADP-ribose) polymerase-1 (PARP-1) in breast cancer of African women and its potential as a targeted therapy. Journal of Cancer Research and Treatment 1: 24-30.

14. Agboola AO, Banjo AA, Anunobi CC, Ayoade BA, Deji-Agboola AM, et al (2014) Molecular profiling of breast cancer in Nigerian women identifies an altered p53 pathway as a major mechanism underlying its poor prognosis compared with British counterpart. Malays J Pathol 36: 3-17.
15. McCarty KS Jr, Miller LS, Cox EB, Konrath J, McCarty KS Sr (1985) Estrogen analyses: correlation of biochemical and immunohistochemical methods using monoclonal antireceptor antibodies. Arch Pathol Lab Med 109: 716-721.

16. Kowalski PJ, Rubin MA and Kleer CG (2003) E-cadherin expression in primary carcinomas of the breast and its distant metastases. Breast Cancer Res 5 : R217-R222

17. Ebili HO, Oluwasola AO, Olopade OI (2014) Molecular subtypes and prognosis of breast cancer. In: Jatoi I, Holloway TL (eds) Personalized Management of Breast Cancer. Future Medicine 1: 21-33.

18. Schroeder JA, Adriance MC, Thompson MC, Camenisch TD, Gendler S (2003) MUC1 alters [beta]-catenin-dependent tumor formation and promotes cellular invasion. Oncogene 22: 1324-1332.

19. Zhang CC, Yan Z, Zhang Q, Kuszpit K, Zasadny K, et al (2010) PF-03732010: a fully human monoclonal antibody against P-cadherin with antitumor and antimetastatic activity. Clin Cancer Res 16: 5177-5188. 